\title{
Advantages of the new loop diuretic torasemide over furosemide in patients with cirrhosis and ascites
}

\author{
A randomized, double blind cross-over trial
}

\author{
Alexander L. Gerbes ${ }^{a}$, Ute Bertheau-Reitha ${ }^{a}$, Christine Falkner ${ }^{b}$, Dieter Jüngst ${ }^{a}$ and Gustav Paumgartner ${ }^{a}$ \\ ${ }^{2}$ Department of Medicine II and 'Department of Clinical Chemistry, Klinikum Grosshadern. University of Mumich, Munich, Germany
}

(Received 4 March 1992)

Torasemide is a new loop diuretic with a longer half-life and longer action than furosemide in healthy subjects. In order to evaluate the pharmacodynamic effects, single oral doses of furosemide $(80 \mathrm{mg})$ and torasemide $(20 \mathrm{mg})$, which were equipotent in healthy subjects, were given to 14 patients with cirrhosis and ascites. Before the study patients underwent an equilibration period of 4 days without diuretics. The drugs were alternated following a randomized double-blind cross-over design after a wash-out period of at least 2 days. Urine was collected at defined intervals for $24 \mathrm{~h}$ after drug administration and blood samples were taken before, $6 \mathrm{~h}$ and $24 \mathrm{~h}$ after medication. Torasemide induced greater cumulative $24 \mathrm{~h}$ diuresis $(2863 \pm 343$ vs. $2111 \pm 184 \mathrm{ml}, p<0.01)$ than furosemide. Torasemide did not differ from furosemide for cumulative $0-6$ h sodium excretion ( $96 \pm 17$ vs. $92 \pm 23$ mmol sodium) but caused a more pronounced cumulative $6-24 \mathrm{~h}$ natriuresis ( $38 \pm 11$ vs. $17 \pm 4 \mathrm{mmol}, p<0.05$ ). Five patients exhibited a weak response to furosemide (0-36 mmol sodium/24 h, median $24 \mathrm{mmol} ; 690-1460 \mathrm{ml}$ urinary volume $/ 24 \mathrm{~h}$, median $1325 \mathrm{ml}$ ). These patients showed significantly higher natriuresis and diuresis following torasemide $(26-136 \mathrm{mmol}$ sodium/24 h, median $78 \mathrm{mmol}, p<0.05 ; 1670-3610 \mathrm{ml}$ urinary volume $/ 24 \mathrm{~h}$, median $2200 \mathrm{ml}, p<0.05$ ). Twenty-four hours after administration of both drugs there were no significant changes in hemodynamic, renal or hormonal parameters. No adverse effects were noted with either treatment. These findings suggest that torasemide might be more advantageous than furosemide in the treatment of ascites due to cirrhosis.

Key words: Cirrhosis; Ascites therapy; Loop diuretic; Pharmacodynamics

\section{Introduction}

In cirrhosis with ascites and decreased effective blood volume the most commonly used loop diuretic, furosemide, may lead to the activation of sodium retaining hormonal systems (1-4), due to its rapid onset and short duration of action. Torasemide is a new loop diuretic of the pyridine-sulfonamido group (5), which exhibits a longer half-life and longer action than furosemide in healthy subjects (6). This diuretic has been found to be more effective than furosemide on a molar basis and, due to its nearly complete bioavailability (7), is equally efficient following oral and parenteral administration. In the present study, single oral doses of torasemide and furosemide, which were equipotent in healthy subjects, were given to patients with cirrhosis and ascites. Each patient was his own control. The aim of this investigation was to study the effects and side-effects of torasemide compared to the standard loop diuretic, furosemide.

\section{Patients and Methods}

Fourteen patients with cirrhosis and ascites were studied (11 male, 3 female; age 36-66 years, median 53 years). Diagnosis was based on history, ultrasound, liver biopsy and laboratory parameters. The etiology of cir-

Correspondence to: Priv. Doz. Dr. Alexander L. Gerbes, Medizinische Klinik II, Klinikum Grosshadern, Universität München, Marchioninistrasse 15, W 8000 München 70, Germany. 
rhosis was alcoholic in 11 , posthepatitic in 2 and cryptogenic in 1 patient. All patients were non-azotemic (serum creatinine levels below $2.0 \mathrm{mg} / 100 \mathrm{ml}$ ), and all serum electrolytes were in the normal range. There was no evidence of heart failure, renal disease, hypertension, diabetes, encephalopathy or recent gastrointestinal bleeding. The nature of the study was explained in detail to the patients and written consent was obtained. The study was designed and performed according to the principles of the Declaration of Helsinki and approved by the local ethical committee.

\section{Protocol of the study}

The investigation began with an equilibration period of at least 4 days without diuretics. Drug administration was followed by a $24 \mathrm{~h}$ observation period. After a washout period of at least 2 days and administration of the other drug there was another $24 \mathrm{~h}$ observation period. During the study patients received a regular diet and did not receive any other diuretic medication. Baseline renal function parameters were investigated in 7 patients and were not different before treatment with either drug. Single oral doses of torasemide $(20 \mathrm{mg})$ and furosemide $(80 \mathrm{mg})$, which were found equipotent in healthy subjects (8), were given to patients on the first experimental day and alternated on the second day of observation according to a randomized double-blind cross-over design. During these days urine was collected at defined intervals for $24 \mathrm{~h}(0-2,2-4,4-6,6-8,8-10,10-24 \mathrm{~h})$ and analyzed for volume, sodium, potassium and chloride. Blood samples for electrolytes, creatinine and other parameters were taken before and $24 \mathrm{~h}$ after drug administration. Blood pressure and heart rate were determined at the same time. Blood samples for plasma renin activity and plasma aldosterone concentrations were collected under basal conditions, 6 and $24 \mathrm{~h}$ after administration of the diuretic, with patients remaining in the supine position for $1 \mathrm{~h}$ preceding the collection. Sodium, potassium and chloride were determined by flame photometry, creatinine by the conventional colorimetric method of Jaffe, and plasma renin activity and plasma aldosterone concentration by a radioenzymatic method as described previously (9).

\section{Statistical analysis}

Results are expressed as the mean and standard error. Statistical significance was tested by a paired and unpaired Student's $t$-test, respectively. A $p$-value of less than 0.05 was considered significant.

\section{Results}

There was no difference in cumulative sodium excretion between torasemide and furosemide $0-6 \mathrm{~h}$ after drug administration (Fig. la). However, in the 6-24 h interval torasemide induced significantly higher natriuresis ( $38 \pm 11$ vs. $17 \pm 4 \mathrm{mmol}$ sodium) (Table 1). Urinary volume was significantly higher following torasemide administration (Fig. 1b, Table 1), and body weight $24 \mathrm{~h}$ after administration was reduced by

(a)
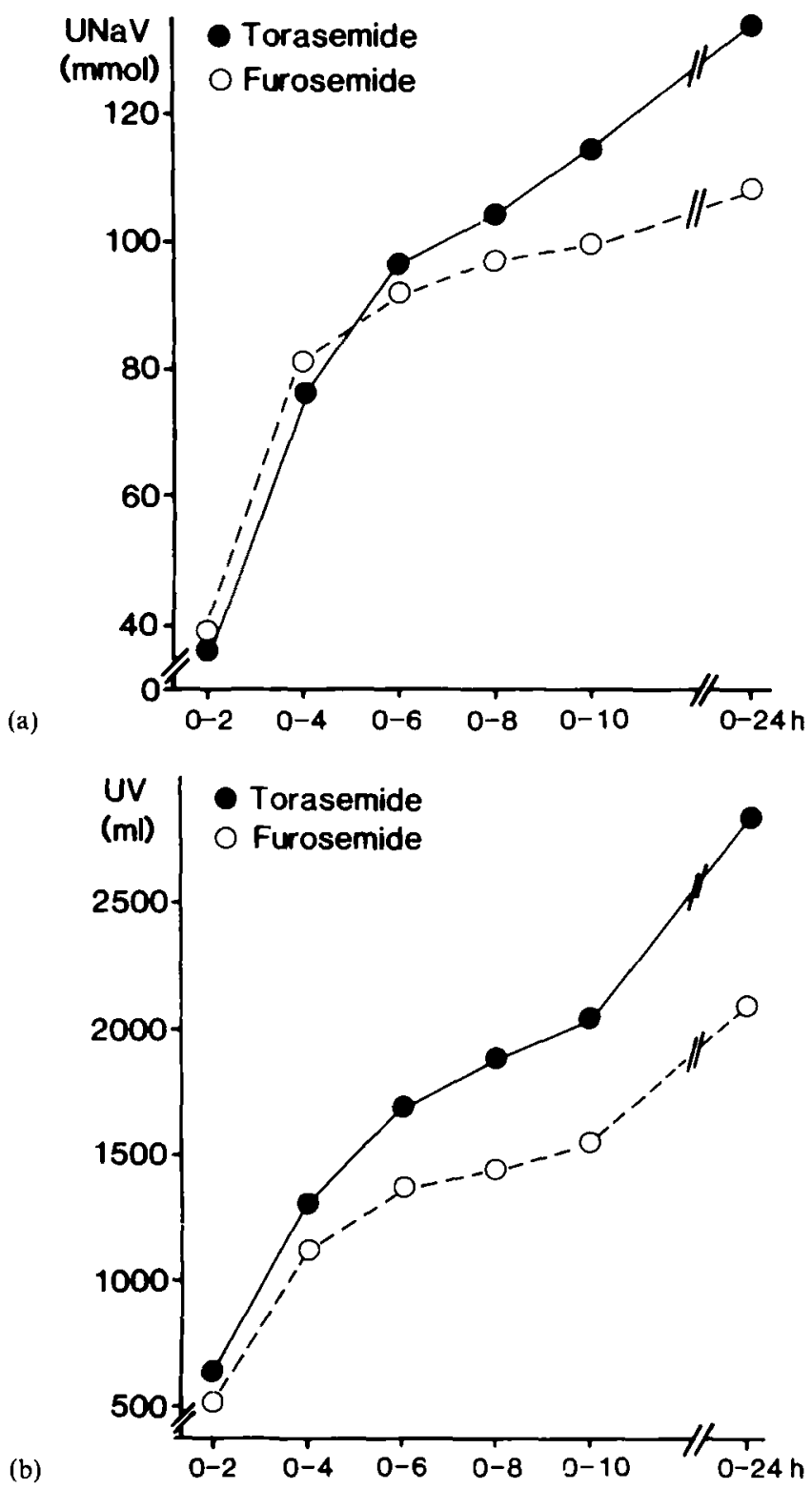

Fig. 1a. Cumulative urınary sodium excretion in a $24 \mathrm{~h}$ period following administration of torasemide $(20 \mathrm{mg}$ p.o.) ( ) and furosemide $(80 \mathrm{mg} \mathrm{p.0.)}(0)$ in 14 patients with cirrhosis and ascites.

Fig. 1b. Cumulative urinary volume in a $24 \mathrm{~h}$ period following administration of torasemide (20 mg p.o.) (O) and furosemide $(80 \mathrm{mg}$ p.o.) $(0)$ in 14 patients with cirrhosis and ascites. 


\section{TABLE 1}

Renal effects of torasemide and furosemide in 14 patients with cirrhosis and ascites in the intervals $0-6,6-24$ and $0-24 \mathrm{~h}$ after admunistration of the drugs

\begin{tabular}{lcc}
\hline & Torasemide & Furosemide \\
\hline $0-6 h$ & & \\
UNaV (mmol) & $95.7 \pm 17.2$ & $92.1 \pm 23.4$ \\
FeNa (\%) & $2.2 \pm 0.5$ & $2.7 \pm 0.7$ \\
UVol (ml) & $1719 \pm 211^{\mathrm{a}}$ & $1377 \pm 237$ \\
UKV (mmol) & $57.5 \pm 7.2$ & $39.9 \pm 5.5$ \\
UClV (mmol) & $139.7 \pm 19.9$ & $123.8 \pm 22.9$ \\
$6-24 h$ & \\
UNaV (mmol) & $38.4 \pm 11.3^{\mathrm{a}}$ & $16.6 \pm 4.4$ \\
FeNa (\%) & $0.58 \pm 0.18$ & $0.38 \pm 0.14$ \\
UVol (ml) & $1144 \pm 233^{\mathrm{a}}$ & $734 \pm 139$ \\
UKV (mmol) & $36.0 \pm 9.7$ & $27.6 \pm 3.5$ \\
UClV (mmol) & $61.1 \pm 17.9^{\mathrm{a}}$ & $23.3 \pm 6.2$ \\
$0-24 h$ & & \\
UNaV (mmol) & $134.0 \pm 21.2$ & $108.5 \pm 25.7$ \\
FeNa (\%) & $1.07 \pm 0.17$ & $1.19 \pm 0.28$ \\
UVol (ml) & $2863 \pm 351^{\mathrm{a}}$ & $2111 \pm 351$ \\
UKV (mmol) & $88.3 \pm 10$ & $68.0 \pm 6.8$ \\
UClV (mmol) & $198.9 \pm 22.9^{\mathrm{a}}$ & $143.6 \pm 24.6$ \\
\hline
\end{tabular}

${ }^{a} p<0.05$ vs. furosemide.

$0.49 \pm 0.29 \mathrm{~kg}$ following furosemide and $0.73 \pm 0.35 \mathrm{~kg}$ following torasemide (not significant).

Serum electrolytes and creatinine, blood pressure and heart rate were not significantly different $24 \mathrm{~h}$ after administration of either drug (Table 2).

In relation to the responses to both drugs in individual patients, the 5 patients with the weakest response to furosemide showed a markedly greater response to torasemide: median 24 h sodium excretion 24 vs. $78 \mathrm{mmol}$ $(p<0.05)$, median 24 h urinary volume 1325 vs. $2200 \mathrm{ml}$ $(p<0.05)$ (Table 3, Fig. 2a,b). In these patients body weight was reduced by torasemide $(0.20 \pm 0.77 \mathrm{~kg})$, but increased $24 \mathrm{~h}$ after furosemide (by $0.12 \pm 0.67 \mathrm{~kg}$ ). In the other 9 patients, compared to furosemide, torasemide induced a slight, but not significant increase in natriuresis and diuresis (Table 3). The 5 patients who responded

\section{Natriuresis [mmol] 0-24h}

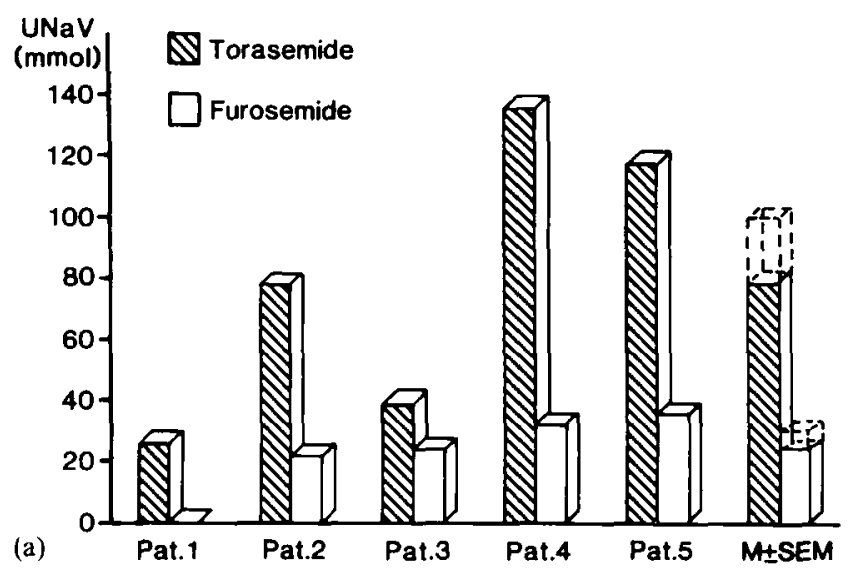

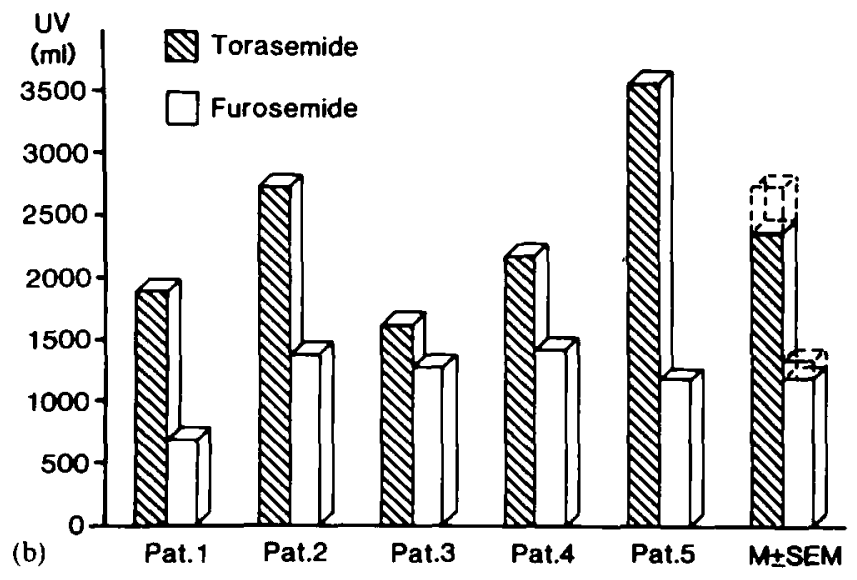

Fig. 2a. Twenty-four-hour urinary sodium excretion in 5 patients with the poorest response to furosemide ( $80 \mathrm{mg} \mathrm{p.o.)} \mathrm{(open} \mathrm{bars)} \mathrm{and} \mathrm{effects}$ of torasemide (20 mg p.o.) (hatched bars) in the same patients.

Fig. 2b. Twenty-four-hour urinary volume in 5 patients with the poorest response to furosemide ( $80 \mathrm{mg}$ p.o.) (open bars) and effects of torasemide (20 mg p.o.) (hatched bars) in the same patients.

TABLE 2

Serum, hemodynamic and hormonal parameters before and $24 \mathrm{~h}$ after administration of torasemide (20 mg p.o.) and furosemide ( $80 \mathrm{mg}$ p.o.), in 14 pattents with cirrhosis and ascites

\begin{tabular}{|c|c|c|c|c|}
\hline & \multicolumn{2}{|l|}{ Torasemide } & \multicolumn{2}{|l|}{ Furosemide } \\
\hline & $0 \mathrm{~h}$ & $24 \mathrm{~h}$ & $0 \mathrm{~h}$ & $24 \mathrm{~h}$ \\
\hline $\begin{array}{l}\text { Serum parameters } \\
\text { Sodium }(\mathrm{mmol} / \mathrm{l}) \\
\text { Potassium }(\mathrm{mmol} / \mathrm{l}) \\
\text { Creatinine }(\mathrm{mg} / 100 \mathrm{ml})\end{array}$ & $\begin{array}{c}136 \pm 1.1 \\
3.9 \pm 0.14 \\
1.02 \pm 0.06\end{array}$ & $\begin{array}{c}136 \pm 1.1 \\
3.7 \pm 0.11 \\
1.03 \pm 0.05\end{array}$ & $\begin{array}{c}136 \pm 1.2 \\
3.9 \pm 0.18 \\
1.07 \pm 0.06\end{array}$ & $\begin{array}{c}135 \pm 1.1 \\
3.9 \pm 0.14 \\
0.99 \pm 0.06\end{array}$ \\
\hline $\begin{array}{l}\text { Mean arterial pressure } \\
(\mathrm{mmHg})\end{array}$ & $90 \pm 3$ & $84 \pm 3.2$ & $88 \pm 4$ & $90 \pm 2.5$ \\
\hline Heart rate $\left(\min ^{-1}\right)$ & $82.6 \pm 2.3$ & $80.8 \pm 2.8$ & $80.9 \pm 3.0$ & $79.1 \pm 1.7$ \\
\hline $\begin{array}{l}\text { Plasma renin actıvity } \\
\text { (ng } \mathrm{Al} / \mathrm{ml} / \mathrm{h})\end{array}$ & $29.9 \pm 6$ & $30.6 \pm 6.9$ & $34.7 \pm 7.1$ & $36.8 \pm 7.3$ \\
\hline $\begin{array}{l}\text { Plasma aldosterone } \\
\text { concentration }(\mathrm{ng} / 100 \mathrm{ml})\end{array}$ & $111.9 \pm 33$ & $132 \pm 42.2$ & $105.7 \pm 28.4$ & $131 \pm 44.1$ \\
\hline
\end{tabular}


TABLE 3

Renal effects of torasemide ( $20 \mathrm{mg}$ p.o.) and furosemide $(80 \mathrm{mg}$ p.o.) in the intervals $0-6 \mathrm{~h}, 6-24 \mathrm{~h}$ and $0-24 \mathrm{~h}$ in the 5 patients with the weakest response to furosemide as compared to the other 9 patients

\begin{tabular}{|c|c|c|c|c|c|}
\hline & & \multicolumn{2}{|l|}{ Torasemide } & \multicolumn{2}{|l|}{ Furosemide } \\
\hline & & $n=5$ & $n=9$ & $n=5$ & $n=9$ \\
\hline$\overline{0-6 \mathrm{~h}}$ & $\begin{array}{l}\text { UNaV (mmol) } \\
\text { FeNa (m) } \\
\text { UVol (ml) } \\
\text { UKV (mmol) } \\
\text { UCIV (mmol) }\end{array}$ & $\begin{array}{l}48.8 \pm 19.7^{\circ} \\
1.67 \pm 0.8 \\
1292 \pm 152 \\
63.8 \pm 15.8 \\
93.4 \pm 26\end{array}$ & $\begin{array}{c}121.8 \pm 20.2 \\
2.49 \pm 0.66 \\
1957 \pm 295 \\
54.1 \pm 7.6 \\
165.4 \pm 24\end{array}$ & $\begin{array}{c}14 \pm 4.8^{a} \\
0.5 \pm 0.16^{a} \\
676 \pm 133.5 \\
30.8 \pm 9.8 \\
40 \pm 13.9^{\prime \prime}\end{array}$ & $\begin{array}{c}136 \pm 26.7 \\
3.98 \pm 0.86 \\
1766 \pm 289 \\
45 \pm 6.3 \\
170 \pm 23\end{array}$ \\
\hline $6-24 h$ & $\begin{array}{l}\text { UNaV (mmol) } \\
\text { FeNa (\%) } \\
\text { UVol (ml) } \\
\text { UKV (mmol) } \\
\text { UClV (mmol) }\end{array}$ & $\begin{array}{c}29.8 \pm 19.5 \\
0.47 \pm 0.28 \\
1132 \pm 433 \\
47.6 \pm 26.4 \\
56.8 \pm 35.5\end{array}$ & $\begin{array}{c}43.1 \pm 14.4 \\
0.64 \pm 0.24 \\
1150 \pm 292 \\
29.6 \pm 5.4 \\
63.4 \pm 21.4\end{array}$ & $\begin{array}{c}9 \pm 4.8 \\
0.49 \pm 0.37 \\
539 \pm 66.8 \\
20.9 \pm 6.4 \\
13.8 \pm 8.6\end{array}$ & $\begin{array}{c}20 \pm 6 \\
0.33 \pm 0.11 \\
842 \pm 209 \\
31.3 \pm 3.8 \\
28.4 \pm 8.1\end{array}$ \\
\hline $0-24 \mathrm{~h}$ & $\begin{array}{l}\text { UNaV (mmol) } \\
\text { FeNa (\%) } \\
\text { UVol (ml) } \\
\text { UKV (mmol) } \\
\text { UClV (mmol) }\end{array}$ & $\begin{array}{c}78.6 \pm 21.1^{\mathrm{a}} \\
0.83 \pm 0.21 \\
2424 \pm 348 \\
89.3 \pm 26.2 \\
149.8 \pm 25.5\end{array}$ & $\begin{array}{r}159.9 \pm 28.4 \\
1.2 \pm 0.23 \\
3108 \pm 506 \\
87.7 \pm 7.7 \\
226.1 \pm 29.8\end{array}$ & $\begin{array}{c}22.8 \pm 6.2^{i 1} \\
0.3 \pm 0.09^{\mathrm{a}} \\
1215 \pm 139^{\mathrm{a}} \\
51.7 \pm 12.4 \\
53.8 \pm 20.1^{4}\end{array}$ & $\begin{array}{c}156 \pm 30 \\
1.68 \pm 0.33 \\
2609 \pm 468 \\
77.1 \pm 6.8 \\
193.6 \pm 23.3\end{array}$ \\
\hline
\end{tabular}

${ }^{a} p<0.05$ vs. the subgroup of 9 patients.

poorly to furosemide did not differ from the other 9 patients regarding age, renal function or liver function. However, these patients did have an increased basal heart rate and decreased blood pressure as well as a trend towards higher basal plasma renin activity and plasma aldosterone concentration (Table 4).

\section{Discussion}

In our study a double-blind randomized cross-over trial was used with each patient as his own control. The effects of $20 \mathrm{mg}$ torasemide were compared with those

\section{TABLE 4}

Characterization of the 5 patients with the weakest response to furosemide and of the 9 other patients investigated

\begin{tabular}{lcc}
\hline & $n=5$ & $n=9$ \\
\hline Sex (male/female) & $2 / 3$ & $9 / 0$ \\
Age (years) & $55.2 \pm 4.3$ & $50.8 \pm 3.1$ \\
Mean arterial pressure (mmHg) & $82.7 \pm 3.2^{\mathrm{a}}$ & $94.8 \pm 3.3$ \\
Heart rate (min ${ }^{-1}$ ) & $89 \pm 3^{\mathrm{a}}$ & $78 \pm 2$ \\
Child-Pugh score & $5 \mathrm{~B}$ & $1 \mathrm{~A} / 5 \mathrm{~B} / 3 \mathrm{C}$ \\
Aminopyrin breath test & $0.232 \pm 0.104$ & $0.211 \pm 0.05$ \\
Prothrombin time (\%) & $74 \pm 1$ & $64 \pm 7.5$ \\
Serum parameters & & \\
Albumin (g/l00 ml) & $3.3 \pm 0.1$ & $3.4 \pm 0.1$ \\
Bilirubin (mg/100 ml) & $2.14 \pm 0.76$ & $2.0 \pm 0.57$ \\
Creatinine (mg/100 ml) & $1.15 \pm 0.01$ & $1.01 \pm 0.04$ \\
Creatinine clearance (ml/min) & $51.3 \pm 10.7$ & $75.8 \pm 10.7$ \\
Sodium (mmol/l) & $132 \pm 1.2^{\mathrm{a}}$ & $138 \pm 1$ \\
Potassium (mmol/l) & $4.1 \pm 0.3$ & $3.87 \pm 0.1$ \\
Plasma renin activity (ng Al/ml/h) & $41.2 \pm 12$ & $27.5 \pm 7.6$ \\
Plasma aldosterone & & \\
concentration (ng/l00 ml) & $170 \pm 68.4$ & $77.4 \pm 17.7$ \\
\hline
\end{tabular}

${ }^{a} p<0.05$ vs. the subgroup of 9 patients. of $80 \mathrm{mg}$ furosemide orally once per day without any other diuretic treatment.

The results of our investigation indicate that although the effects of torasemide were not different from furosemide for natriuresis in the first $6 \mathrm{~h}$ following administration, torasemide does significantly better in the $6-24 \mathrm{~h}$ interval. The effects on urinary volume were significantly greater for torasemide than for furosemide. The effects on plasma renin activity and plasma aldosterone concentration, however, were not different for the two drugs. Therefore, differences in the activation of the reninaldosterone system are not a likely explanation.

The natriuretic potency of torasemide and furosemide in healthy subjects has mostly been investigated with a dose ratio of $1: 2$ on basis of weight $(6,12)$. Whereas in these studies the ratio was equipotent, in patients with oedema of various origins the ratio shifted to approximately 1:8 (13). Studies on patients with cirrhosis and ascites used a $1: 2$ or $1: 2.5$ ratio of torasemide and furosemide $(10,11)$. For the present study we chose a $1: 4$ ratio. This was based on two considerations: (a) We intended to have a slightly conservative approach and use lower torasemide doses relative to the furosemide doses than in other studies $(6,10-12)$. (b) In another study in healthy subjects using the same protocol with $20 \mathrm{mg}$ torasemide and $80 \mathrm{mg}$ furosemide we found an equal natriuretic and diuretic effect for both doses (8).

Two studies comparing torasemide with furosemide in patients with cirrhosis and ascites have been published so far $(10,11)$. The differences in design, however, make discussion and comparison of their results with ours rather difficult. Brunner et al. compared a single oral 
dose of $20 \mathrm{mg}$ torasemide to $40 \mathrm{mg}$ furosemide. Unfortunately the patients had no interval without diuretics before the study and received furosemide until the last day preceding the investigation. This study does not provide information on the administration of aldosterone antagonists, diet or the conditions under which the patients were kept preceding the study. Ten patients were randomly assigned to the torasemide and 9 to the furosemide group. Both groups differed in age (approx. 10 years), weight (approx. $5 \mathrm{~kg}$ ), systolic blood pressure $(7-12 \mathrm{mmHg})$ and heart rate $(6 \mathrm{bpm})$. In this investigation a longer diuretic action was found for torasemide, but there was no difference in urinary volume or sodium excretion $24 \mathrm{~h}$ after administration of either drug.

Laffi et al. (11) investigated 24 patients with cirrhosis and ascites under standard diet hospital conditions, 5 days after the initiation of a diuretic therapy of $200 \mathrm{mg}$ daily of an aldosterone antagonist. The patients were then randomly assigned to receive either $25 \mathrm{mg}$ furosemide or $10 \mathrm{mg}$ torasemide orally once a day for 3 days. Under these conditions a significantly higher loss of body weight and a significant increase in natriuresis were observed with the aldosterone antagonist and torasemide combination than with the aldosterone antagonist and furosemide.

Our finding that the 5 patients with the weakest response to furosemide showed a marked and significantly better natriuresis and diuresis after torasemide is of particular interest. This is probably not due to cross-over effects, since torasemide was given as the first drug in 3 and furosemide in 2 of these patients. It has been shown that activation of the renin-aldosterone system is inversely correlated to the renal response to furosemide $(12,14-16)$. Indeed the group of 5 patients had a trend towards higher plasma renin activity and aldosterone concentration before treatment than the other 9 patients included in the study. On the other hand, since torasemide and furosemide act at the same site of the loop of Henle,

\section{References}

I Bcrnardi M, De Palma R, Trevisani F, Santini C, Patrono D, Motta R. Serradei D, Gasbarrini G. Effects of a new loop diuretic (muzolimine) in cirrhosis with ascites: comparison with furosemide. Hepatology 1986; 6: 400-5.

2 Ring-Larsen $\mathrm{H}$, Henriksen $\mathrm{JH}$. Pathogenesis of ascites formation and hepatorenal syndrome-humoral and hemo-dynamic factors. Semin Liver Dis 1986; 6: 341-52.

3 Schölmerich J. Aszites. Berlin, Heidelberg, New York: SpringerVerlag, 1991.

4 Conn H. Diuresis of ascites: Fraught with or free from hazard. Gastroenterology 1977; 73: 619-21.

5 Delarge J. Chemistry and pharmacological properties of the their effects should be counteracted in the same way by any increased sodium retention in the distal tubule.

It has been shown that the renal effects of furosemide are related to a stimulation of renal prostaglandin production. In the poor responders to furosemide in our study prostaglandin production was possibly increased more by torasemide than by furosemide. In a recent study (I1) torasemide did not affect the urinary excretion of prostaglandin metabolites but, due to the limitations of a single $24 \mathrm{~h}$ urine collection the data of this study cannot exclude a role for urinary arachidonic metabolites in modulating the natriuretic effects of torasemide.

Finally, there may be differences in the pharmacokinetics of these patients, which may account for the observed differences in pharmacodynamics (17). In the study by Brunner et al. (10) the serum elimination halflife of torasemide was longer than that of furosemide in patients with cirrhosis and ascites. The possible differences in pharmacokinetics for the patients investigated in our study remain to be elucidated. Whatever the reasons for the differences observed are, the present data suggest advantages of torasemide over furosemide particularly in patients with cirrhosis and ascites who respond poorly to furosemide. If these data are confirmed by long-term treatment studies, torasemide could be preferred to furosemide as the loop diuretic of choice in these patients.

\section{Acknowledgements}

F. Ringel and J. Nagl are thanked for the preparation of the manuscript. We thank E. Greiner for the drawing of the illustrations. Drs. Achhammer, Böhlke, Helming, Metz and Piesche of Boehringer Mannheim, Germany, are thanked for their cooperation and for providing the drug samples. This study was presented at the 92nd Digestive Disease Week 1991, New Orleans. The data are part of a doctoral thesis by U. Bertheau-Reith.

pyridine-3-sulfonylurea derivate torasemide. Drug Res 1988; 38 : 144-50.

6 Lesne M. Comparison of the pharmacokinetics and pharmacodynamics of torasemide and furosemide in healthy volunteers. Drug Res 1988; 38: 160-3.

7 Barr WH. Smith HL, Karnes HT, et al. Torasemide doseproportionality of pharmacokinetics and pharmacodynamics. In: Krück F. Mutschler E, Knauf H, eds. Progress in Pharmacology and Clinical Pharmacology, Vol. 8, Ist ed. Stuttgart, New York: Gustav Fischer. 1990; 29-37.

8 Bertheau-Reith U. Pharmakodynamik und -kinetik des Schleifendiuretikums Torasemid im Vergleich zu Furosemid bei Probanden und Patienten mit Leberzirrhose. Dissertation, LudwigsMaximilians University, Munich, in preparation. 
9 Gerbes AL, Wernze H, Arendt RM, Riedel A, Sauerbruch T. Paumgartner G. Atrial natriurctic factor (ANF) and renin-aldosterone in volume regulation of patients with cirrhosis. Hepatology 1989; 9: 417-22.

10 Brunner G, von Bergmann K, Häcker W, von Möllendorff E. Comparison of diuretic effects and pharmacokinetics of torasemide and furosemide after a single oral dose in patients with hydropically decompensated cirrhosis of the liver. Drug Res 1988; 38: 176-9.

11 Laffi G, Marra F, Buzzelli G, et al. Comparison of the effects of torasemide and furosemide in nonazotemic cirrhotic patients with ascites: A randomized, double-blind study. Hepatology 1991; 13: $1101-5$.

12 Dupont AG, Gerlo E, van der Niepen P, Laekeman G, Piepsz A. Renal pharmacodynamic effects of torasemide and furosemide in normal man. Drug Res 1988; 38: 172-5.

13 Herchuelz A. Deger F, Douchamps J, Ducarne H, Broekhuysen
J. Comparative pharmacodynamics of torasemide and furosemide in patients with oedema. Drug Res 1988; 38: 180-3.

14 Villeneuve J-P, Verbeeck RK. Wilkinson GR, Branch RA. Furosemide kinetics and dynamics in patients with cirrhosis. Clın Pharmacol Ther 1986; 40: 14-20.

15 Pérez-Ayuso RM, Arroyo V, Planas R, et al. Randomized comparative study of efficacy of furosemide versus spironolactone in nonazotemic cirrhosis with ascites. Gastroenterology 1983; 84: 961-8.

16 Gatta A, Angeli P, Caregaro L, Menon F, Sacerdoti D, Merkel C. A pathophysiological interpretation of unresponsiveness to spironolactone in a stepped-care approach to the diuretic treatment of ascites in nonazotemic currhotic patients. Hepatology 1991; 14: 231-6.

17 Pinzani M, Daskalopoulos G, Laffi G, Gentilini P. Zipser RD. Altered furosemide pharmacokinetics in chronic alcoholic liver disease with ascites contributes to diuretic resistance. Gastroenterology 1987; 92: 294-8. 